\title{
IZABELA GATKOWSKA
}

Uniwersytet Jagielloński, Kraków

\section{Empiryczna sieć powiązań leksykalnych}

\section{Wprowadzenie}

Potrzeba reprezentowania znaczeń jednostek języka za pomocą postaci sieci semantycznej ujawniła się w badaniach nad sztuczną inteligencją rozpoczętych na przełomie lat 60. i 70. XX wieku. Badacze poszukujący algorytmów rozumienia tekstu (Schank 1975) doszli do wniosku, że algorytm rozumiejący tekst lub rozpoznający obraz musi mieć dostęp do informacji, która nie występuje bezpośrednio w tekście czy obrazie. W przeciwnym przypadku algorytm nie potrafi poprawnie zinterpretować tak naturalnych w ludzkiej komunikacji sekwencji wypowiedzi: Wczoraj dostałam spaniela Cieszę się, że masz psa. Chcąc umożliwić algorytmowi dostęp do informacji nieobecnej bezpośrednio w wypowiedzi, można posłużyć się siecią zbudowaną ze znaczeń i zależności (relacji) zachodzących pomiędzy znaczeniami. Algorytm, który zlokalizuje jednostkę analizowanej wypowiedzi w tak rozumianej sieci, zyskuje dostęp do wszystkich znaczeń, które wiążą się z analizowaną jednostką, a więc uzyska wiedzę, że np. spaniel łączy się bezpośrednio ze znaczeniem pies oraz pośrednio ze znaczeniem zwierzę.

Sieć semantyczną można zbudować ręcznie, analizując odpowiednio liczny zbiór zdań reprezentatywnych dla każdego z umieszczonych w sieci znaczeń — tak zbudowano i buduje się nadal wychodzące $\mathrm{z}$ różnych założeń sieci łączące znaczenia za pomocą relacji semantycznych i pragmatycznych np. WordNet (Miller i wsp. 1998), FrameNet (Fillmore 2000) czy Cyc (tzw. ontologia). Jednak różne założenia leżące u podstaw wymienionych sieci spowodowały, że sieci różnią się nie tylko zbiorem relacji semantycznych, np. WordNet ma ich kilkanaście, a Cyc ponad 20000 (Pohl 2009), ale też pojmowaniem obiektów, między którymi relacje zachodzą. WordNet i Cyc są słownikami pojęć i jednostek słownika, a FrameNet jest słownikiem struktur semantycznych, za pomocą których można opisać znaczenie jednostki leksykalnej w zdaniu. 
Sieć reprezentującą znaczenia jednostek języka można także zbudować empirycznie, pozyskując naturalny zbiór powiązań pomiędzy znaczeniami jednostek słownika za pomocą eksperymentu psycholingwistycznego, np. poprzez test swobodnych skojarzeń słownych — w ten sposób zbudowano np. Edinburgh Associative Thesaurus (EAT, Kiss, Armstrong, Milroy, Piper 1973). Jednak sam eksperyment dostarcza tylko danych o powiązaniach, a sieć zyskuje przydatność wówczas, gdy dokonamy interpretacji powiązań pomiędzy znaczeniami. Jako pierwszy zwrócił na to uwagę H.H. Clark (1970), wskazując możliwość interpretacji skojarzeń za pomocą metod znanych językoznawstwu. Jednak praca Clarka była studium skoncentrowanym na objaśnianiu mechanizmów powstawania skojarzeń leksykalnych i nie analizowała konkretnej sieci. Chcąc opisać sposób reprezentowania znaczeń jednostek leksykalnych w sieci zbudowanej eksperymentalnie, musimy poklasyfikować ujawniające się w wyniku eksperymentu zależności pomiędzy znaczeniami, gdyż zakładamy, że nie tylko fakt powiązania z innymi znaczeniami, ale także jakość powiązań definiuje znaczenie jednostki leksykalnej w sieci. Zdefiniowane w ten sposób 'naturalne' znaczenie jednostki leksykalnej można porównać ze znaczeniem tej samej jednostki słownika zbudowanym przez leksykografów. Niniejszy tekst przedstawi budowę empirycznej sieci powiązań leksykalnych, próbę klasyfikacji występujących w sieci powiązań pomiędzy znaczeniami oraz wstępną charakterystykę definiowanego przez sieć znaczenia rzeczownika.

\section{Empiryczna sieć powiązań leksykalnych}

\subsection{Podstawa eksperymentalna — test swobodnych skojarzeń słownych}

Diagnostyczną przydatność analizy powiązań leksykalnych zauważyli amerykańscy psychiatrzy G. Kent i A.J. Rosanoff, którzy w roku 1910 opracowali i przeprowadzili test swobodnych skojarzeń słownych. W trakcie testu przebadano 1000 zdrowych osób o różnym wykształceniu i zawodach, prosząc badanych o podanie pierwszego przychodzącego na myśl skojarzenia wywołanego przez wyraz-bodziec. Zbadano w ten sposób skojarzenia dla 100 wyrazów-bodźców (głównie rzeczowników i przymiotników). Lista Kent-Rosanoffa została przetłumaczona na kilka języków, dla których powtórzono eksperyment, umożliwiając w ten sposób badania porównawcze. Badania skojarzeń słownych kontynuowano: Palermo, Jenkins (1964), Postman, Keppel (1970), Kiss, Armstrong, Milroy, Piper (1973), Moss, Older (1996), Nelson, McEvoy, Schreiber (1998), a powtarzalność wyników pozwalała zmniejszać liczbę badanych osób przy jednoczesnym zwiększaniu liczby wyrazów-bodźców, np. 500 badanych i 200 wyrazów (Palermo, Jenkins 1964) czy 100 badanych i 8400 wyrazów (Kiss, Armstrong, Milroy, Piper 1973). Zwiększanie użytej w testach liczby wyrazów sprawiło, że wyniki testów stały się materiałem ciekawym dla językoznawstwa, a prowadzony przez wiele lat eksperyment Kiss, Armstrong, Milroy, Piper (1973) pozwolił nawet na zbudowanie tezaurusa dla języka angielskiego - 
Edinburgh Associative Thesaurus (EAT). Eksperymenty prowadzące do budowy sieci skojarzeń leksykalnych prowadzi się także współcześnie, np. De Deyne, Storms (2008). Po roku 2000 do badań nad swobodnymi skojarzeniami słownymi włączyła się też lingwistyka komputerowa, poszukując naturalnego modelu łączliwości znaczeń, np. Melinger, Weber (2006), S. Schulte im Walde, S. Borgwaldt, R. Jauch (2012).

W Polsce badania swobodnych skojarzeń słownych przeprowadziła w latach 1964/1965 I. Kurcz. Podstawą eksperymentu I. Kurcz była pełna (100 wyrazów) lista Kent-Rosanoffa, w tłumaczeniu na język polski. W teście uczestniczyło 1000 studentów Uniwersytetu Warszawskiego i Politechniki Warszawskiej. Kompletne wyniki oraz krótki artykuł wprowadzający opublikowano w VII tomie „Studiów Psychologicznych” z 1967r. Autorski eksperyment (Gatkowska 2014), który pozwolił zbudować sieć powiązań leksykalnych opisaną w niniejszym tekście, nawiązuje bezpośrednio do eksperymentu Kurcz, zob. 4.1.

\subsection{Charakterystyka empirycznej sieci leksykalnej}

Wynikiem testu swobodnych skojarzeń słownych jest tzw. lista skojarzeniowa, tj. zbiór wyrazów stanowiących odpowiedzi związane z konkretnym bodźcem. Jednak w roku 1973 brytyjscy badacze (Kiss, Armstrong, Milroy, Piper 1973) zaobserwowali, że jeśli przebadamy odpowiednio liczny zbiór wyrazów bodźców, prowadząc eksperyment cyklicznie, tj. używając odpowiedzi uzyskanych w cyklu pierwszym jako bodźców w cyklu następnym, to bodźce i zbiory odpowiedzi tworzą sieć. Uzyskana eksperymentalnie sieć leksykalna to zbiór jednostek leksykalnych (wyrazów, np. dom, pies i jednostek wielosegmentowych, np. panna młoda, czarna owca) oraz zbiór powiązań między jednostkami leksykalnymi.

Sieć leksykalna. Jeśli przyjmiemy, że istnieją wyrazy A, B, C, D, E i skojarzenia, tj. pary bodziec — odpowiedź
$\mathrm{A} \rightarrow \mathrm{D}$
np. morze $\rightarrow$ woda
$\mathrm{A} \rightarrow \mathrm{B}$
np. morze $\rightarrow$ rzeka
$\mathrm{B} \rightarrow \mathrm{C}$
np. rzeka $\rightarrow$ ocean
$\mathrm{C} \rightarrow \mathrm{A}$
np. ocean $\rightarrow$ morze
$\mathrm{D} \rightarrow \mathrm{B}$
np. woda $\rightarrow$ rzeka
$\mathrm{B} \rightarrow \mathrm{E}$
np. rzeka $\rightarrow$ rwąca

To zbiór par bodziec — odpowiedź tworzy sieć o postaci 

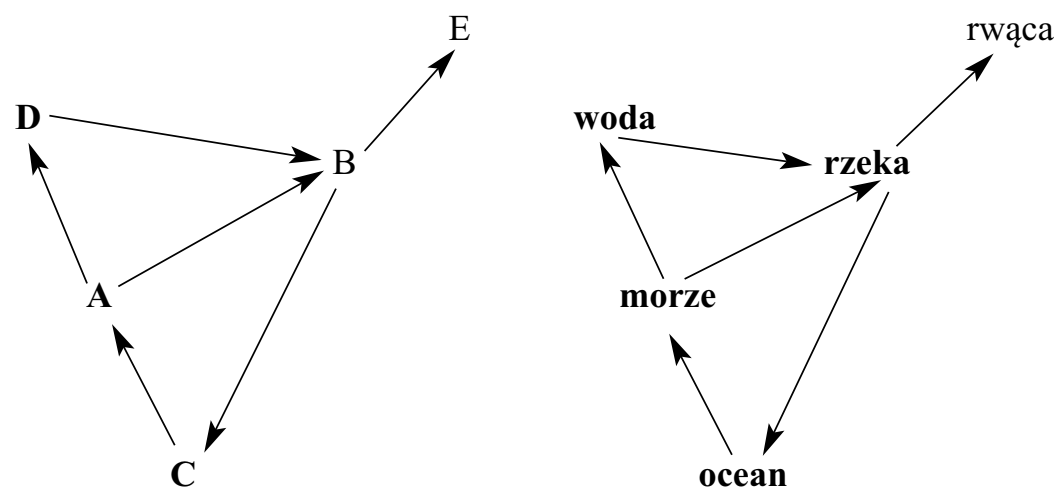

Wyrazy są węzlami sieci, a strzałki oznaczają powiązanie i jego kierunek — zawsze od bodźca do odpowiedzi. Powiązanie o tak zdefiniowanym kierunku zachodzące pomiędzy dwoma węzłami sieci np. A $\rightarrow$ B, jest dla węzła A powiązaniem wychodzącym a dla węzła B powiązaniem przychodzącym. Tak więc w naszej przykładowej sieci węzeł morze ma dwa powiązania wychodzące: morze $\rightarrow$ woda, morze $\rightarrow$ rzeka oraz jedno powiązanie przychodzące ocean $\rightarrow$ morze. Sekwencja powiązań tworzy w sieci ścieżkę, np. $\mathrm{A} \rightarrow \mathrm{B} \rightarrow \mathrm{C}$, gdzie $\mathrm{A}$ jest węzłem początkowym, a $\mathrm{C}$ węzłem końcowym ścieżki. Długość ścieżki określana poprzez liczbę powiązań w ścieżce nie ma formalnych ograniczeń. W sieci leksykalnej wyróżniamy dwa rodzaje ścieżek: zamknięte i otwarte.

Ścieżki zamknięte to takie, w których wyraz jest jednocześnie węzłem początkowym i końcowym węzłem ścieżki, np. $\mathrm{A} \rightarrow \mathrm{D} \rightarrow \mathrm{B} \rightarrow \mathrm{C} \rightarrow \mathrm{A}$, czyli morze $\rightarrow$ woda $\rightarrow$ rzeka $\rightarrow$ ocean $\rightarrow$ morze. Konkretny węzeł może rozpoczynać wiele ścieżek zamkniętych; w naszym przykładzie będą to sekwencje powiązań: $\mathrm{A} \rightarrow \mathrm{D} \rightarrow \mathrm{B} \rightarrow \mathrm{C} \rightarrow \mathrm{A}$, czyli morze $\rightarrow$ woda $\rightarrow$ rzeka $\rightarrow$ ocean $\rightarrow$ morze oraz $\mathrm{A} \rightarrow \mathrm{B} \rightarrow \mathrm{C} \rightarrow \mathrm{A}$, czyli morze $\rightarrow$ rzeka $\rightarrow$ ocean $\rightarrow$ morze.

Ścieżki otwarte to ścieżki, w których węzeł początkowy ścieżki jest różny od węzła końcowego; w naszym przykładzie będą to ścieżki np. $\mathrm{A} \rightarrow \mathrm{D} \rightarrow \mathrm{B} \rightarrow \mathrm{E}$, czyli morze $\rightarrow$ woda $\rightarrow$ rzeka $\rightarrow$ rwaca oraz np. $\mathrm{A} \rightarrow \mathrm{B} \rightarrow \mathrm{E}$, czyli morze $\rightarrow$ rzeka $\rightarrow$ rwaca.

Każdy wyraz, który znajduje się sieci i jest powiązany z innymi wyrazami, tworzy węzeł leksykalny. Istnieją węzły leksykalne, w których wyraz węzłowy ma powiązania wychodzące i przychodzące (wyraz mający ten typ węzła to wyraz, który był bodźcem), oraz węzły, w których wyraz węzłowy jest charakteryzowany tylko przez powiązania przychodzące, gdyż wyraz węzłowy nie był bodźcem tylko odpowiedzią do wyrazów bodźców.

Statystyczna analiza sieci leksykalnych (Steyvers, Tenenbaum 2005) pokazuje, że sieć leksykalna i słowniki semantyczne (Roget's Thesaurus, WordNet) mają wspólne cechy strukturalne i że cechy te odróżniają sieć powiązań leksykalnych od analizowa- 
nych za pomocą tych samych metod statycznych sieci będących przedmiotem badań innych niż językoznawstwo dyscyplin naukowych. Tak więc analiza statystyczna potwierdza językoznawczą intuicję i można powiedzieć, że wszystkie przychodzące i wychodzące powiązania wyrazu węzłowego oraz wszystkie ścieżki zamknięte i otwarte, w których wyraz węzłowy jest węzłem początkowym, definiują znaczenie wyrazu węzłowego. Jednak analiza językoznawcza węzła leksykalnego empirycznej sieci leksykalnej musi wykroczyć poza analizę statystyczną, powinna bowiem uwzględniać fakt, że uzyskane empirycznie powiązania pomiędzy znaczeniami wyrazów występujących w sieci mają właściwą sobie silę i jakość.

Siła i kierunek powiązania. Siła powiązania to stosunek liczby odpowiedzi łączących bodziec A z odpowiedzią B do liczby wszystkich odpowiedzi uzyskanych dla bodźca A. Przykładowo, gdy liczba wszystkich odpowiedzi dla bodźca A wynosi 95, z czego 49 przypada na odpowiedź B, to siła powiązania A-B wynosi 52\% (49/95 po zaokrągleniu). Siła powiązania jest związania z jego kierunkiem, co znaczy, że powiązania wychodzące i przychodzące mają własną (odrębną) siłę powiązania. Przykładowo siła powiązań wychodzących i przychodzących przymiotnika kiszona i rzeczownika kapusta jest różna. Gdy bodźcem jest kiszona, tj. kiszona $\rightarrow$ kapusta siła powiązania wynosi 83,18\% ${ }^{1}(737$ odpowiedzi kapusta z 886 odpowiedzi), zaś gdy bodźcem jest kapusta, tj. kapusta $\rightarrow$ kiszona siła powiązania wynosi już tylko 48,85\% (426/886). Można więc powiedzieć, że zależność związana z kierunkiem siły powiązania określa stosunek pomiędzy znaczeniami - dla znaczenia kiszona połączenie ze znaczeniem kapusta jest najważniejsze, natomiast dla znaczenia kapusta powiązanie z kiszona jest mniej ważne, gdyż kiszona to tylko jedna z właściwości przysługujących kapuście, występująca obok: warzywo 4,47, głowa 3,9, zielona 2,87 itp. Jednak siła powiązania może być tylko wartością pomocniczą. Opis znaczenia węzła leksykalnego sieci możemy uzyskać, gdy uwzględnimy jakość powiązania.

Kierunek i jakość powiązania. Jakość powiązania to zależność semantyczna zachodząca pomiędzy znaczeniami, np. powiązanie ręka - ciało, noga-krzesło jest powiązaniem pomiędzy częścią a całością. Przyjmujemy, że zależność semantyczna ma swój kierunek, w naszym przykładzie od części do całości — w tym przypadku kierunek zależności semantycznej jest zgodny z kierunkiem skojarzenia bodziec — odpowiedź. Podobną zgodność kierunku skojarzenia i zależności semantycznej obserwujemy w parach krzesło — noga, ciało — noga, gdzie zależność prowadzi od całości do części.

Są jednak liczne powiązania semantyczne, których kierunek jest niezależny od kierunku skojarzenia, np. ryba - morze i morze - ryba wyrażają zależność pomiędzy zwierzęciem a miejscem, w którym zwierzę żyje; zależność ta prowadzi od zwierzęcia do miejsca. Nazwijmy tę zależność miejsce_charakterystyczne i przyjmijmy, że nazwy

\footnotetext{
${ }^{1} \mathrm{~W}$ dalszej części tekstu wartość liczbowa siły powiązania oznacza procent odpowiedzi.
} 
jakości powiązań zachodzących pomiędzy węzłami sieci będziemy nazywać wyznacznikami jakości powiązania.

Istnieją wreszcie w sieci powiązania, np. ręka - noga, noga - oparcie, którym nie da się przyporządkować zależności semantycznej, a jedyną wspólną własnością wymienionych znaczeń jest to, że stanowią części określonej całości, tj. ciała i krzesła. Powiązania takie objaśnia ścieżka prowadząca od części-bodźca do części-odpowiedzi poprzez całość, a więc ręka - ciało - noga, noga - krzesto - oparcie. Podobne choć mające innych mechanizm - zjawisko obserwujemy w powiązaniach baranina - wetna, owca - sweter; tu w każdym przypadku ścieżka ma inną strukturę, odpowiednio: baranina - owca - runo - wetna - owca - runo - wetna - sweter. Powiązania, w których zależność pomiędzy węzłami można objaśnić tylko poprzez ścieżkę w sieci, będziemy nazywać powiązaniami odległymi.

\section{Jakościowa klasyfikacja powiązań}

Klasyfikację jakościową powiązań prowadzoną z językoznawczego punktu widzenia jako pierwszy zaproponował Herbert H. Clark (1970). Zgodnie z psychologiczną tradycją badań nad skojarzeniami Clark przyjmuje, że skojarzenia dzielą się na semantyczne, tj. takie, w których pomiędzy bodźcem a odpowiedzią zachodzi zależność semantyczna, np. dom - dach, tóżko - sen, oraz dźwiękowe (clang and rhyme), czyli takie, w których pomiędzy bodźcem a odpowiedzią zachodzi podobieństwo brzmieniowe, np. baranina - pani nina. Dalej, zgodnie z tradycją, skojarzenia semantyczne Clark dzieli skojarzenia na paradygmatyczne i syntagmatyczne. Skojarzenia paradygmatyczne to takie, w których wyraz bodziec i wyraz odpowiedź należą do tej samej części mowy. Natomiast skojarzenia syntagmatyczne to takie, w których bodziec i odpowiedź należą do różnych części mowy. Jednak prowadzona przez Clarka analiza powiązania bodziec - odpowiedź jest już prowadzona z językoznawczego punktu widzenia. Znaczenie jest reprezentowane jako zbiór cech syntaktycznych (Chomsky 1965), np. mężczyzna: [+Noun, +Det, +Count, +Animate, +Human, +Adult, +Male], a zależność pomiędzy znaczeniami wyrażają operujące na cechach reguły, np. reguła minimalnego kontrastu, zmieniająca znak jednej cechy, powiedzmy + Male $=>-$ Male , przekształca jednostkę słownika mężczyzna w kobieta: [+Noun, +Det, +Count, +Animate, +Human, +Adult, -Male]. Clark postuluje szereg reguł opisujących zależności paradygmatyczne, stwierdzając zarazem, że znacznie trudniej zbudować reguły dla powiązań syntagmatycznych, gdyż te - zdaniem Clarka - powinny operować na syntaktycznych cechach selekcyjnych, które tylko częściowo reprezentują znaczenie wyrazów łączących się w zdaniu, a więc trudno za ich pomocą odróżnić na przykład szeroką łączliwość przymiotnika biały od silnie ograniczonej łączliwości przymiotnika kiszony w zasadzie tylko: kapusta, ogórek. Drugim powodem utrudniającym formułowanie reguł generujących skojarzenia syntagmatyczne jest fakt, że wiele skojarzeń syntagmatycznych, np. chleb - masto, igła - nitka, mlotek - gwóźdź, by pojawić się w zdaniu, wymaga wyrazu pośredniczącego, tj. chleb z masłem, igła z nitka, młotek wbija gwóźdź. 
Dlatego w pracy Clarka pojawia się tylko ogólna reguła generująca skojarzenia syntagmatyczne. Szczególny przypadek skojarzeń syntagmatycznych tworzą skojarzenia składnikowe (idiom completion), w których bodziec i odpowiedź są składnikami wielowyrazowej jednostki leksykalnej, np. skojarzenie owca - czarna wobec jednostki leksykalnej czarna owca czy owca - wilk wobec wilk w owczej skórze. W konsekwencji Clark przyjmuje, że skojarzenia syntagmatyczne są wyabstrahowane ze struktur syntaktycznych ${ }^{2}$. Dziś można powiedzieć, że skojarzenia paradygmatyczne i syntagmatyczne reprezentują zależności semantyczne przechowywane w słowniku, które można opisać za pomocą semantycznych relacji leksykalnych.

\subsection{Relacje leksykalne}

Od czasu fundamentalnego studium o słownictwie Platona, w którym Lyons usystematyzował strukturalistyczny model relacji paradygmatycznych, wprowadzając przy tym neogreckie nazwy relacji, relacje leksykalne stały się przedmiotem intensywnych badań prowadzonych w obrębie różnych dyscyplin naukowych. Bardzo obszerne omówienie rezultatów tych badań zawiera książka Murphy (2003). Z naszego punktu widzenia najistotniejsze są wyniki prac informatycznych zmierzających do budowy wielopoziomowych taksonomii służących reprezentacji wiedzy nazywanych ontologiami (Sowa 2000) i taksonomii kognitywistycznych, których celem była rekonstrukcja systemu pojęciowego - synsety, tj. zbiory quasi-synonimów w słowniku WordNet miały wyznaczać pojęcia (Miller i wsp. 1998). Budowa wielopoziomowych taksonomii często zmuszała do rezygnacji z klasycznych językoznawczych kryteriów rozróżniania relacji paradygmatycznych i syntagmatycznych: "Sets of elements which can be substituted one for another in a given context are said to be in paradigmatic relationship; elements which combine to form a larger unit are said to be in syntagmatic relationship." (Lyons 1970: 16). Rozluźnienie kryteriów ma swe konsekwencje, np. pragmatyczna z założenia, zawierająca kilka tysięcy relacji, ontologia Cyc obok relacji paradygmatycznych ma też relacje operujące ,w poprzek” taksonomii, pozwalające interpretować zjawiska syntagmatyczne (Pohl 2009). Stawiająca sobie cel poznawczy taksonomia WordNet interpretuje niektóre zjawiska syntagmatyczne za pomocą relacji paradygmatycznych, np. relacje owca - baranina, owca - owczarnia są interpretowane za pomocą relacji część - całość (holonimia) ${ }^{3}$, a przecież baranina to mięso z owcy, a owczarnia to miejsce przeznaczone dla owiec ${ }^{4}$. Z drugiej strony budowa taksonomii ujawniła szereg zjawisk (Murphy 2003), które były wcześniej zauważane (Lyons 1984), jednak w kontekście klasyfikacji powiązań w sieci leksykalnej mogłyby być przedmiotem

2 “[...] syntagmatic associations are not merely continuous fragments of normal speech, [...] but rather responses that bear only an abstract relationship to normal speech" (Clark 1970: 283).

${ }^{3}$ Tak Słowosieć: http://plwordnet.pwr.wroc.pl/wordnet/3a00a6ac-c0f8-11e4-bdb2-7a5d273e87eb. Owczarnia w użyciu metaforycznym: boża owczarnia, oznacza zbiór wiernych, a nie zwierząt.

${ }^{4}$ Co potwierdza opis wyrazu owczarnia: http://plwordnet.pwr.wroc.pl/wordnet/aad2e462-c0f8-11e4afff- $7 \mathrm{a} 5 \mathrm{~d} 273 \mathrm{e} 87 \mathrm{eb}$. 
poważnych analiz językoznawczych. Wymieńmy najważniejsze, gdyż dotyczą zależności, wykazujących wysoką siłę powiązania. Pierwsza dotyczy zależności typ — okaz (hiponimia), gdzie zgodnie z definicją znaczenie podrzędne, np.jamnik, dziedziczy cechy nadrzędnika pies. Jednak są znaczenia nadrzędne, np. mebel, które nie mają cech dziedziczonych przez podrzędniki, np. krzesto, kanapa; podobnie warzywo - kapusta, kolor - czerwony itp. Można więc postawić pytanie, czy mebel, warzywo, kolor to rzeczywiste nadrzędniki, czy też tylko etykiety identyfikujące zbiory różnych obiektów lub stanów. Powiązania tego typu są obecne w sieci: (krzesto - mebel 869/47, tj. 5,41, kapusta - warzywo 872/39, tj. 4,47).

Kolejny problem stanowią zależności pomiędzy okazami, czyli podrzędnikami tego samego nadrzędnika. Jeśli przyjąć za Lyonsem, że zależność krzesło — kanapa określa relacja incopatibility, to możemy przyjąć, że jedynym wspólnym elementem łączącym oba znaczenia jest wspólny nadrzędnik mebel. Jednak powstaje wątpliwość, czy relacja incompatibility zachodzi także pomiędzy podrzędnikami dziedziczącymi cechy wspólnego nadrzędnika, np. spaniel - jamnik. Kolejne wątpliwości dotyczą relacji całość - część (meronimia). Zasadnicza wątpliwość odnosi się do sytuacji, w której całość nie ma wyodrębnionej struktury, np. chleb - kromka, zboże - worek, oraz sytuacji, gdy część maszyny lub urządzenia pełni określoną funkcję w stosunku do całości, np. napęd w powiązaniach silnik — samochód, żagiel - statek. Tu można bowiem upatrywać zależności syntagmatycznych. Jednak trudno rozstrzygnąć wspomniane wątpliwości bez osobnych badań, dlatego dla potrzeb jakościowej klasyfikacji powiązań przyjmujemy klasyczny Lyonsowski model relacji paradygmatycznych z jednym wyjątkiem: powiązania pomiędzy podrzędnikami tego samego nadrzędnika (ko-hiponimy), np. wolowina - baranina, oraz powiązania pomiędzy częściami tej samej całości, np. siedzenie - oparcie (ko-meronimy), będziemy traktować jako powiązania objaśniane przez ścieżkę otwartą, w której węzłem początkowym i końcowych są podrzędniki lub części, a węzłem pośredniczącym jest nadrzędnik lub całość, np. baranina - mięso - wołowina oraz siedzenie - krzesło - oparcie. Innymi słowy, powiązania te będziemy traktować jako odległe.

Poszukując modelu leksykalnych relacji syntagmatycznych napotykamy istotną trudność. Nie możemy się bowiem odwołać do skomplikowanego modelu tzw. słownika wyjaśniająco-kombinatorycznego (Mel'čuk 2007), którego abstrakcyjne funkcje leksykalne, opisujące łączliwość znaczeń w zdaniu, nie nadają się do opisu powiązań w sieci leksykalnej. Drugie potencjalne źródło zachodzących pomiędzy znaczeniami relacji syntagmatycznych, czyli słownik FrameNet, także sprawia kłopot, gdyż FrameNet nie definiuje bezpośrednich zależności pomiędzy znaczeniami jednostek słownika (Lexical Units). Znaczenia te wchodzą w relacje pośrednie poprzez uczestnictwo w ramie (frame), która jest strukturą semantyczną podobną do scenariusza (Schank, Abelson 1977), opisującą znaczenie abstrakcyjnego predykatu, np. revenge 'zemsta' w odniesieniu do konkretnej sytuacji za pomocą swoistych dla ramy ról semantycznych (FEs Frame Elements), np. avenger (mściciel), offender (krzywdziciel), 
injury (krzywda), injured party (pokrzywdzony), punishment (kara), (Fillmore 2000). Jednostki leksykalne (jednostki słownika LU) wypełniając role w ramie dziedziczą zależności, w jakie wchodzi rola. Twórcy słownika FrameNet przyznają, że rzeczowniki mają także ramy o ograniczonej strukturze, gdyż często występują z wyrażeniami określających ich rodzaj (okaz), tworzywo, z którego zostały zrobione, sposób, w jaki zostały zrobione, ich przeznaczenie lub użycie. Jednak niestety właściwości te nie zostały zdefiniowane jako ramy, lecz jako role (Frame Elements) w konkretnych ramach ${ }^{5}$. Tak więc nie możemy sklasyfikować powiązań syntagmatycznych posługując się ramami, możemy jednak odwoływać się do idei ram i sposobu ich definiowania, definiując system wyznaczników opisujących powiązania syntagmatyczne występujące w empirycznej sieci powiązań leksykalnych.

\subsection{Wyznaczniki jakości powiązania}

Wracając do rozpatrywanego wcześniej przykładu powiązania ryba - morze możemy powiedzieć, że zależność miejsce_charakterystyczne zachodzi pomiędzy zwierzęciem a obiektem, będącym wytworem przyrody. Jednak dopiero rozpatrzenie kolejnych przykładów, np. owca - taka, sędzia - sad, lekarz - szpital prowadzi do wniosku, że zależność miejsce_charakterystyczne zachodzi pomiędzy obiektami ożywionymi: ryba, owca (zwierzę), sędzia, lekarz (osoba) a obiektami, które są wytworami natury morze, taka lub obiektami wytworzonymi przez człowieka: sad, szpital. Można więc powiedzieć, że powiązanie sklasyfikowane jako miejsce_charakterystyczne zachodzi pomiędzy znaczeniami należącymi do określonych klas. Innymi słowy, wyznacznik powiązania ma swój zakres wyznaczany przez klasy znaczeń. Dla określania zakresu wyznaczników jakości powiązania przyjmujemy istnienie następujących klas:

Obiekty, głównie rzeczowniki, są jednostkami leksykalnymi, które reprezentują elementy rzeczywistości percypowane przez ludzkie zmysły. Co oznacza, że za obiekt uznajemy każdą jednostkę języka, która wskazuje na osobę (chłopiec, żotnierz), zwierzę (pies, owca), roślinę (drzewo, kwiat), obiekt naturalny (góra, rzeka), zjawisko naturalne (wiatr, światto) lub artefakt, czyli rzecz (krzesło, zamek), dzieło (składające się z rzeczy i informacji abstrakcyjnej, np. ksiazka, muzyka) lub artefakt abstrakcyjny (religia, prawo).

Własności, głównie przymiotniki, przysłówki i rzeczowniki odczasownikowe, są jednostkami leksykalnymi, które reprezentują percypowane za pomocą zmysłów lub umysłu stałe cechy obiektów (duży, ciężki, biały, madry, kapryśny) lub percypowane za pomocą zmysłów lub umysłu czasowe stany obiektów (choroba, głód, radość, załamanie).

\footnotetext{
5 "We do recognize that artifact and natural kinds of nouns also have a minimal frame structure of their own. For example, artifacts often occur together with expressions indicating their sub-type, the material of which they are made, their manner of production, and their purpose/use; these are defined as FEs in the frames for various types of artifacts" (R uppenh ofer i in. 2010: 5).
} 
Akcje, głównie czasowniki i rzeczowniki odczasownikowe, to jednostki leksykalne, reprezentujące działania wywoływane przez obiekty i operujące na obiektach (spać, sen, przybić, siedzieć).

Znaczenia złożone, głównie rzeczowniki, to jednostki leksykalne reprezentujące sytuacje, czyli wywołane przez akcję lub zdarzenie statyczne stany więcej niż jednego obiektu (kłopot, spadek) oraz zdarzenia, czyli dynamiczne sytuacje zbudowane z obiektów, akcji i stanów powiązanych zależnościami przyczynowymi (mecz, wykład,powódź).

Powiązania paradygmatyczne

Jak powiedzieliśmy wcześniej, przyjmujemy klasyczny językoznawczy (Lyons 1963) model powiązań paradygmatycznych. Wyróżniamy więc następujące wyznaczniki powiązania:

Hiponimia, czyli powiązanie pomiędzy znaczeniem nadrzędnym i podrzędnym. Zależność ta zachodzi pomiędzy obiektami lub stanami i jest reprezentowana przez dwie relacje oraz powiązania odległe objaśniane przez ścieżkę w sieci:

hiponimia (typ - okaz) prowadząca od nadrzędnika do podrzędnika, np.: pies spaniel, zwierze - owca, mebel - krzesto;

hiperonimia (okaz - typ), prowadząca od podrzędnika do nadrzędnika, np.: spaniel-pies, owca-zwierze, krzesto - mebel;

ko-hiponimia, powiązanie odległe objaśniane przez ścieżkę w sieci zachodzące pomiędzy podrzędnikami tego samego nadrzędnika, np.: spaniel — jamnik, baranina - wotowina, zielony - czerwony.

Meronimia, czyli powiązanie pomiędzy częścią a całością. Zależność ta właściwa obiektom jest reprezentowana przez dwie relacje i powiązanie odległe:

holonimia (część - całość) prowadząca od części do całości, np.: noga - stót, dach - dom, pies - sfora, kromka - chleb;

meronimia (całość - część) prowadząca od całości do części, np.: góra - szczyt, chlopiec - glowa, ciało - ręka, owca - runo;

ko-meronimia, objaśniana za pomocą ścieżki w sieci zależność pomiędzy częściami tej samej całości, np.: ręka - noga, stopa - głowa, drzwi-okno.

Synonimia, tj. zależność zachodząca pomiędzy obiektami, stanami lub akcjami, które w określonym kontekście mają znaczenia identyczne lub zbliżone, np.: mnich zakonnik, problem - klopot, praca - robota.

Antonimia, tj. zależność zachodząca pomiędzy obiektami, stanami lub akcjami, których znaczenia są przeciwstawne w określonym kontekście, np.: kawaler - żonaty, dobry — zly, jasno - ciemno, wchodzić — schodzić.

Komplemetarność, tj. zależność zachodząca pomiędzy obiektami lub stanami powiązanymi w sposób naturalny, których znaczenia wchodzą w opozycję, np.: kobieta — mężczyzna, słońce - księżyc, dzień - noc, przypływ - odptyw. 
Powiązania syntagmatyczne

\section{Cechy fizyczne}

— rozmiar — określa zależność pomiędzy: osobami, zwierzętami, bytami nieożywionymi, w tym obiektami naturalnymi i artefaktami (rzeczami), a przysługującymi obiektowi cechami fizycznymi, określającymi percypowany za pomocą wzroku (względny) lub poddający się pomiarowi (bezwzględny) wymiar fizyczny, np.: rzeka - szeroka 6,02, rzeka - głęboka 2,89, chata - mała 0,6, rzeka - wielka 0,58, rzeka - dtuga 3,7, rzeka - ptytka 0,23 ;

— ksztalt — określa zależność pomiędzy: osobami, zwierzętami, bytami nieożywionymi, w tym obiektami naturalnymi i artefaktami (rzeczami), a percypowaną za pomocą dotyku lub wzroku zewnętrzną formą obiektu, np.: stót - okragty 10,43, stót kwadratowy 0,23, stót - ptaski 0,58, rzeka - meandry 0,23, rzeka-kreta*6 0,23 , wijąca się 0,23 ;

- kolor - określa zależność pomiędzy: osobami, zwierzętami, obiektami naturalnymi i artefaktami (rzeczami) a właściwościami ich powierzchni percypowanymi za pomocą wzroku zależnie od tego, jak odbijają lub emitują światło, np.: łodyga - zielona 2,41, ziemia - brązowa 0,23, księżyc - srebrny 0,23, żólty 0,23;

- tekstura - określa zależność pomiędzy: osobami, zwierzętami, bytami nieożywionymi, w tym obiektami naturalnymi i artefaktami (rzeczami), a właściwościami powierzchni obiektu percypowanymi za pomocą wzroku lub dotyku, np.: dywan miękki 6,34, miękkość 0,23, dywan - kudłaty 0,23, dywan - puszysty 1,38, dywan puch 0,23, dywan - puchaty 0,23, stót - twardy 0,35;

- waga - określa zależność pomiędzy: osobami, zwierzętami, obiektami naturalnymi i artefaktami (rzecz) a względną masą obiektu, określaną poprzez siłę, jakiej trzeba użyć, by unieść obiekt, np.: młotek - ciężki 0,46, motyl-lekkość 2,27, lekki 1,7 ;

— temperatura - określa zależność zachodząca pomiędzy: osobami, zwierzętami, obiektami naturalnymi i artefaktami (rzeczami) a względnym stopniem intensywności ciepła obecnego w obiekcie lub substancji percypowanym przez dotyk lub wskazywanym przez termometr, np.: rzeka - zimna 0,23 , wódka - zimna 0,92 ;

— właściwość_swoista - określa zależność pomiędzy: osobami, zwierzętami, obiektami naturalnymi lub artefaktami (rzeczami) a stanami lub akcjami, określającymi specyfikę obiektu, np.: rzeka - rwaca 5,67, rzeka - wartka 1,16, rzeka - nurt 0,93, prad 0,81, rzeka - mokra 0,58, rzeka - bystra 0,23, rzeka - dzika 0,23, rzeka

\footnotetext{
${ }^{6}$ Wyrazy przytaczamy w takiej formie, w jakiej zostały napisane przez uczestników eksperymentu, oznaczając gwiazdką (*) formy błędne.
} 
— sucha 0,$23 ;$ dywan - brudny 0,69, - stary 0,23 ; ręka - złamana 0,34 , odcięta 0,23 , sprawna 0,23 ; butelka - rozbita 0,46 ; krzesto - stoi 0,69 ; lew - siła 0,46, silny 0,46 .

\section{Cechy psychiczne}

Cechy psychiczne przysługujące ludziom i zwierzętom:

- charakter - określa zależność pomiędzy: osobami, zwierzętami a sposobem bycia lub postawami wyróżniającymi obiekt, np.: żotnierz — odwaga 1,04, waleczny 0,23 , dzielny 0,23 , złodziej - sprytny 0,23 , lew - groźny 0,57 , odważny 0,34 , drapieżnik 0,23 , walka 0,34 , waleczny 0,34 ;

— umysł - określa zależność pomiędzy: osobami a ich zdolnością rozumowania i rozumienia rzeczywistości, szczególnie w odniesieniu do zależności abstrakcyjnych (umysłowość), np.: dziewczyna-mądra 0,68, glupia 0,23.

\section{Cechy przyporzadkowane}

— nazwa - określa zależność pomiędzy obiektami ożywionymi, osobami, zjawiskami naturalnymi, obiektami nieożywionymi a ich nazwami własnymi, np.: rzeka —Wisła 15,86, miasto - Kraków 30,62, król-Maciuś 11,25, Kazimierz 0,8, lew Simba 0,57;

- wiedza - określa zależności pomiędzy obiektami naturalnymi, zjawiskami, osobami, zwierzętami, roślinami i artefaktami, stanowiące wynik poznania naukowego, doświadczenia zawodowego, znajomości języka obcego lub informacji przekazywanych przez media, np.: pamięć - hipokamp 0,34, mózg 10,52, todyga - biologia 0,23, ser-Szwajcaria 0,46, Francja 0,23, dywan-Persja 0,69, baranina-judaizm 0,12, rzeka-river* 0,12, religia-Jezus 0,56, Chrystus 0,23; muzyka-Chopin 0,35, baranina - gangster 0,46 ;

— stereotyp - określa zależność pomiędzy: osobami lub artefaktami a szeroko przyjętym uproszczonym wyobrażeniem, zbiorem sądów lub przekonań, np.: ksiądzpedofil 1,28, złodziej 0,93, złodziej - polityk 0,57, lekarz - konowat 0,46, lekarz tapówka 0,23 , alkohol-śmierć 0,34 , baranina - zoofilia 0,12 .

\section{Stosunek obiektu do akcji lub zdarzenia}

— działanie określa zależność zachodzącą pomiędzy osobami, zwierzętami, obiektami naturalnymi lub zjawiskami a typowymi, charakterystycznymi akcjami powodowanymi przez obiekt (obiekt sprawcą akcji), np.: złodziej - kraść 3,99, krasc* 0,23, ukraść 0,34 , kradnie 1,37 , doktor - badanie 0,35 , leczy 0,58 , leczyć 0,46 , leczenie 0,46 , żolnierz - walczy 0,7 , walczyć 0,46 , strzelać 0,35 , strzela 0,23 , zabijać 0,23 , owca- 
beczy 0,43 , beczenie 0,23 , bee 0,23 , rzeka - plynie 4,63, plynie* 0,23 , plynaca 0,23 , flow*7 0,23, rzeka - plynąc 1,04 , kwiat - zapach 4,08, pachnie 0,68;

— udzial - określa zależność pomiędzy osobami lub zwierzętami a sytuacjami, stanami lub zdarzeniami, w których osoba uczestniczy, np.: żotnierz - walka 1,28, złodziej — kradzież 10,26, kradziez* 0,91, kradzierz* 0,34, rabunek 0,34, a także pomiędzy osobami a zdarzeniami, w których uczestniczą, np. żotnierz - wojna 11,25, złodziej-napad 0,68 ;

— przeznaczenie - wyznacznik — określa zależność pomiędzy obiektami (rzeczy, dzieła, artefakty abstrakcyjne) a akcjami wyrażającymi powód, dla którego rzecz została zrobiona lub istnieje, oznacza: do czego obiekt służy, np.: krzesto - siedzieć 8,75, igła - szyć 0,93, nożyczki-ciać 20,84, dom-mieszkać 0,57;

— użyteczność - zachodzi pomiędzy obiektami i zjawiskami naturalnymi, zwierzętami i roślinami a wykonywanymi przez osoby akcjami, określającymi użycie obiektu w konkretnym celu; ludzkie czynności nadają tworom natury przeznaczenie, np.: rze$k a$ - ptywanie 0,12, góra - wspinaczka 0,5, morze - plywać 0,35, stońce - opala 0,34 , opalać się 0,23 .

\section{Zależności funkcjonalne}

—miejsce_charakterystyczne - określa zależność pomiędzy: osobami lub zwierzętami a artefaktami lub obiektami naturalnymi, w których osoba lub zwierzę prowadzi działania charakterystyczne, np.: król - zamek 0,69 , ksiadz — parafia 1,97 , plebania 0,58 , owca - góry 1,03 , taka 1,03 , hala 0,91 , pole 0,68 , pastwisko 0,46 , owca — zagroda $0,23 \%$, orzet - gniazdo 0,34 ;

- domena - określa zależność między osobą a artefaktem abstrakcyjnym, stanowiącym jej obszar działań, np.: ksiądz-religia 3,6, sprawiedliwość - sędzia 1,25, doktor - medycyna 2,88, doktor - nauka 0,69;

- współdzialanie - określa zależność pomiędzy osobami, zwierzętami lub osobami i zwierzętami, wykonującymi działania prowadzące do określonego wspólnego celu, np.: ksiadz - katolik 0,58, ministrant 0,35 , owca - baca 0,68, pasterz 0,57, pies 0,34 ;

— cel — zależność zachodząca pomiędzy: osobami a obiektami lub stanami, które są obiektem ludzkich działań lub stanowią wynik tych działań, np.: złodziej - pieniadze 3,88 , pieniadze* 0,23 , moneta 0,23 , monety 0,23 , portfel 2,74 , torebka 0,46 , czasu 0,91 , dusz 0,34 , tup 0,8 , telefon 0,23 , zegarek 0,23 , złoto 0,23 , samochodów 0,23 , doktor-zdrowie 1,15 ;

\footnotetext{
${ }^{7}$ Forma użyta przez uczestnika eksperymentu.
} 
— posiadanie — stan posiadania lub kontrolowania czegoś; określa zależność pomiędzy osobami lub zwierzętami a obiektami (osoby, zwierzęta, rośliny, rzeczy, obiekty naturalne), np.: dziecko - rodzina 1,7 , matka 1,59 , rodzic 1,47 , rodzice 1,36 , mama 1,25 , dom - wtasny 0,8 , wlasny* 0,23 ;

— użycie - określa zależność pomiędzy osobami a obiektami naturalnymi i artefaktami, służącymi jako narzędzie, środek do realizacji celu, np.: doktor - lek 0,46, lekarstwo 0,35, młotek - kowal 1,04;

— wyznacznik odżywianie - określa zależność pomiędzy obiektami ożywionymi (osobami, zwierzętami i roślinami) a obiektami naturalnymi, artefaktami stanowiącymi pokarm, np.: niemowle - mleko 0,35, owca - trawa 0,23, pająk-owad 7,31, mucha 1,14;

— wyznacznik źródło - zachodzi pomiędzy obiektami (osoby, zwierzęta, rośliny, obiekty naturalne, zjawiska, rzeczy lub miejsca charakterystyczne) a rzeczami, zjawiskami lub artefaktami abstrakcyjnymi; wskazuje na to, skąd coś pochodzi, gdzie ma swój początek lub z czego zostało uzyskane, np.: baran - mięso 3,6, mleko - krowa 0,5, mleko - matka 0,8, owca - runo 0,46, chleb - piekarnia 0,79 , muzyka - instrument 0,81 , radio 0,58 , religia - Bóg 8,01, stońce - światło 5,15, lampa - światto 25,4 ;

— material — to zależność zachodząca pomiędzy obiektami naturalnymi, roślinami lub rzeczami stanowiącymi tworzywo (surowiec) a rzeczami, które są lub mogą być zrobione z tego tworzywa, np.: kwiecie - bukiet 3,51, wianek 1,7, kapusta - bigos 0,92 , kapuśniak 0,8 , sałatka 0,46 , gołąbki 0,34 , surówka 0,23 , z grochem 0,23 , groch 0,23, zupa 0,23, pierogi 0,23 , butelka - szklana 1,3, plastik 0,46, dom - drewno 0,23, cegła 0,23 , mleko - masto 0,46 ;

— ubiór — określa zależność pomiędzy osobami a rzeczami, w które osoba się ubiera, by chronić ciało, lub stanowiącymi składnik odzieży, np.: chłopiec — spodnie 1,35, spodenki 1,24, szelki 0,56, ogrodniczki 0,23, piżama 0,23 ;

— atrybut - określa zależność pomiędzy obiektami (osoby, zwierzęta, rośliny, rzeczy, miejsca charakterystyczne) a identyfikującymi częściami ciała, składnikami obiektu lub rzeczami charakterystycznymi dla obiektu określanego lub pomiędzy artefaktami abstrakcyjnymi a rzeczami symbolizującymi obiekt określany, np.: mężczyzna - broda 0,91, zarost 0,57, lew - grzywa 6,09, kobieta - szminka 0,23, złodziej-kominiarka 0,46, maska 0,46, opaska 0,23, worek 0,23, kościót - krzyż11,06, sprawiedliwość - waga 2,52, temida 0,8 ;

— komplet - określa zależność pomiędzy rzeczami, które łączy wspólne przeznaczenie; zazwyczaj jedna z rzeczy wnosi dodatkowe cechy podnoszące jakość całości, np.: łóżko (sen, spać) — pościel (sen, spać), chleb (jedzenie) - masło (jedzenie), stól-krzesło. 
Wszystkie pary łączone przez wyznacznik komplet wyróżniają bardzo mocne skojarzenia zwrotne, np.: łóżko - pościel 8,5, pościel - tóżko 33,2, chleb- masło 6,09, masło - chleb 12,2, stót - krzesło 16,5, krzesło -stół 22,54, igła - nitka 32,71, nitka - igła 40,02, młotek - gwóźdź 21,2, gwóźdź - młotek 30. Często oba wchodzące w zależność obiekty mają w swoim węźle leksykalnym ten sam czasownik, oznaczający to samo przeznaczenie, np.: łóżko - pościel, spać - spanie. Są jednak przypadki, gdy oba obiekty wchodzące w zależność mają w swoich węzłach leksykalnych różne czasowniki, np. stót - jedzenie, określające jedną z możliwych czynności wykonywanych z udziałem stołu, krzesło - siedzieć;

— zawartość — określa zależność pomiędzy artefaktami lub obiektami naturalnymi a artefaktami lub obiektami naturalnymi, pełniącymi funkcję pojemnika lub ogranicznika, (obiekt przechowywany i obiekt przechowujący), np.: chleb - chlebak 0,23, masło - maselniczka 0,58, wódka - kieliszek 2,06, butelka 1,49, bania 0,34 [kieliszek — regionalizm krakowski], kieliszki 0,23, 100* 0,23, rzeka - koryto 0,81, rzeka brzeg 0,23.

\section{Zależności przestrzenne i czasowe}

— lokalizacja — określa zależność przestrzenną pomiędzy obiektami (osoby, zwierzęta, rośliny, obiekty naturalne, artefakty); zależność jest względna, mamy obiekt lokalizujący i lokalizowany, np.: dom - ogród 2,41, podwórko 0,23 , osiedle 0,23 , wieś 0,46 , dywan - kurz 0,58, rzeka - doptyw 0,23, lampa - sufit 0,79, dywan - podłoga 7,38;

— orientacja - określa położenie obiektu lub jego części względem stron ludzkiego ciała lub stron świata, np.: ręka - lewa 3,19, baszta - północna ${ }^{8}$;

— lokalizacja_w_czasie — określa zależność pomiędzy obiektami ożywionymi, obiektami nieożywionymi a stanami lub artefaktami abstrakcyjnymi (godzina, dzień, miesiąc), stanowiącymi określenia czasu, np.: kwiecie - wiosna 4,42, maj 1,36, majowe 0,57 , wiosenne 0,45 , lato 1,13 , księżyc — noc 17,24 , pótnoc 0,23 , zmierzch 0,34 , ciemno 0,23 , zachód 0,23 .

\section{Stosunek między stanami}

— współwystępowanie — określa zależność pomiędzy stanami, sytuacjami, akcjami lub zdarzeniami a stanami towarzyszącymi lub współwystępującymi, np.: praca wysilek 1,58 , trud 1,47, obowiązek 0,9 , obowiąki 0,23, pasja 0,34, pamięć - sesja 0,34;

— intensywność - określa zależności pomiędzy stanem, sytuacją, akcją, zdarzeniem lub zjawiskiem a stanem określającym subiektywnie percypowany stopień nasilenia stanu, sytuacji, akcji lub zdarzenia, np.: praca - ciężka 11,63, trudna 1,69, ciez-

\footnotetext{
${ }^{8}$ Przykład, który nie występuje w naszej sieci.
} 
ka* 1,13, cięzka* 1,02, męczaca 0,34 , tatwa 0 , radość - duża 0,56 , ogromna 0,45, ktopot - duży 2,78 , wielki 2,67 , maty 1,39 , spory 0,23 ktopot - poważny 0,23 , światlo jasne 11,06, rażace 0,34;

— oznaka - określa zależność pomiędzy ukrytymi (niepoddającymi się percepcji) stanami lub sytuacjami a percypowanymi sygnałami [symptomami] ich istnienia reprezentowanymi przez inny stan lub akcję, np.: radość — uśmiech 13,09, śmiech 2,6, uśmiech 1,2, tzy 0,23, hurra 0,23, smiech* 0,23, skok 0,23, zlość - krzyk 1,95, grymas 0,8, czerwony 0,8, czerwień 0,46 , płacz 0,34 , choroba - goraczka 0,58 , ból 11,45 , praca-pot 0,11 .

\section{Przyczynowe}

— przyczynowość — określa zależność zachodzącą pomiędzy stanami, sytuacjami, akcjami lub zdarzeniami, gdzie jedno ze znaczeń stanowi przyczynę, a drugie skutek, np.: radość - życie 2,93, z życia 1,81 , wiosna 0,79 , zabawa 0,79 , wesele 0,56 , święta 0,56 , dzieciństwo 0,34 , lato 034 , wolne 0,23 , przyjaźn 0,23 , wakacje 0,23 , wygrana 0,23, praca - pieniadze 5,64, zarobki 2,03, ból - rana 5,66, zlość — klótnia 0,8, kłopot - troska 2,2, choroba - problem 0,23.

Możliwa jest też przyczynowość niejawna (implicit causation) zachodząca wówczas, gdy obiekt sprawca wywołujący przyczynę (stan, sytuacja, akcja, zdarzenie) reprezentuje (zastępuje) przyczynę, lub gdy obiekt podlegający akcji lub zdarzeniu stanowiącemu przyczynę reprezentuje (zastępuje) skutek, tj. sytuację lub zdarzenie, np.: radość - dziecko 1,35, dzieci 1,13, mama 0,23, radość - stońce 2,03, tęcza 0,23, praca-ksiażka 0,34, ztodziej-strata 0,46, stońce - opalenizna 0,91 , niemowle - opieka 0,35, muzyka - radość 1,16, muzyka - mitość 1,04. Definicja przyczynowości implicytnej jest wzorowana na opisie FrameNet, ramy causation_scenario, causation.

\section{Stosunek obserwatora do znaczenia wyrazu bodźca}

—identyfikacja- określa zależność pomiędzy obiektami a ich klasyfikacją będącą wynikiem akcji lub procesu identyfikowania (rozpoznania) swoistości obiektu przez obserwatora, np.: kobieta - ja 0,23, moja 0,34, mężczyzna - on 1,13;

- ocena - określa pozytywny lub negatywny stosunek do obiektu lub stanu, będący wynikiem subiektywnej postawy obserwatora, np.: baranina - fuj 0,35 , niedobre 0,23, kobieta - diabet 0,11, alkohol-pyszności 0,11.

\section{Powiazania sktadnikowe}

Składnik określa powiązanie pomiędzy wyrazami, które można zidentyfikować jak składniki wielosegmentowej jednostki leksykalnej, np.: owca - czarna $=>$ czarna owca, owca - pęd => owczy pęd, owca - cała => wilk syty i owca cała. 
Przedstawiona lista wyznaczników uwzględnia wszystkie istotne właściwości powiązań pomiędzy znaczeniami, które ujawniły się podczas analizy węzłów zbudowanych wokół bodźców prymarnych. Zaproponowany zestaw wyznaczników traktujemy jako propozycję wstępną. Będzie ją można zweryfikować w trakcie analizy całej sieci empirycznych powiązań leksykalnych.

Zdajemy sobie sprawę z tego, że może dojść do sytuacji, w której konkretne powiązanie pomiędzy dwoma węzłami sieci można niesprzecznie opisać za pomocą dwu wyznaczników, np. powiązania ksiądz - sutanna12,06, żotnierz - mundur 5,45, lekarz — kitel 0,58 można sklasyfikować za pomocą wyznacznika ubiór oraz za pomocą wyznacznika atrybut, bowiem ubiór jest ściśle związany z domeną aktywności konkretnej osoby. Jednak zjawisko to można prosto reprezentować w strukturze formalnej sieci. Zarówno siła powiązania, jak i wyznaczniki jakości powiązania są etykietami opisującymi powiązanie zachodzące pomiędzy dwoma węzłami sieci. Nie ma bowiem ograniczeń co do liczby etykiet i jakości informacji reprezentowanych przez etykiety.

\section{Węzeł leksykalny rzeczownika a słownikowa definicja znaczenia}

\subsection{Podstawa empiryczna}

Podstawą analiz jest sieć powiązań leksykalnych, którą zbudowano za pomocą eksperymentu autorskiego. W badaniu swobodnych skojarzeń słownych uczestniczyło 900 studentów UJ (Wydziału Zarządzania i Komunikacji Społecznej UJ, Wydziału Matematyki i Informatyki oraz Wydziału E AGH). Jako wyrazów bodźców użyliśmy 63 rzeczowniki z polskiego tłumaczenia listy Kent-Rosanoffa, którego dokonała I. Kurcz (1967), były to tzw. bodźce prymarne. Drugą grupę bodźców, tzw. bodźce sekundarne, stanowiły wyrazy będące najczęstszymi skojarzeniami w eksperymencie Kurcz, średnio 5 najczęstszych odpowiedzi do bodźca prymarnego. Jeśli dana odpowiedź pojawiała się dla różnych bodźców prymarnych, np. biaty dla doktor, ser, owca, to wyraz jako bodziec sekundarny pojawił tylko raz. Bodźce sekundarne występowały w takiej formie gramatycznej, w jakiej pojawiły się jako odpowiedź w eksperymencie Kurcz, a więc np. biała, wieku, do papieru. W efekcie bodźce prymarne i sekundarne to 322 wyrazy, w tym 192 rzeczowniki, 103 przymiotniki, 15 czasowników (w tym imiesłowy czynne), 6 nazw własnych: Maciuś, Lear, Tatry, Warszawa, Wieliczka, Wisła oraz wyrażenia do papieru, na świat, nie ma, z dziurami, wuja Toma, za wsią. Uzyskana w wyniku w wyniku eksperymentu sieć liczy: 11224 węzły leksykalne oraz 50849 powiązań (relacji). Węzły leksykalne to wyrazy notowane w „Słowniku fleksyjnym języka polskiego” (Lubaszewski i in. 2001). W tym: 7757 rzeczowników $(69,1 \%), 2459$ przymiotników (21,9\%), 744 czasowniki (6,6\%) i 264 (2,4\%) wyrazy należące do pozostałych części mowy. Sieć wykazuje duże podobieństwo strukturalne do współcześnie budowanej sieci języka holenderskiego (De Deyne, Storms 2008), gdzie: rzeczowniki to 72\%, przy- 


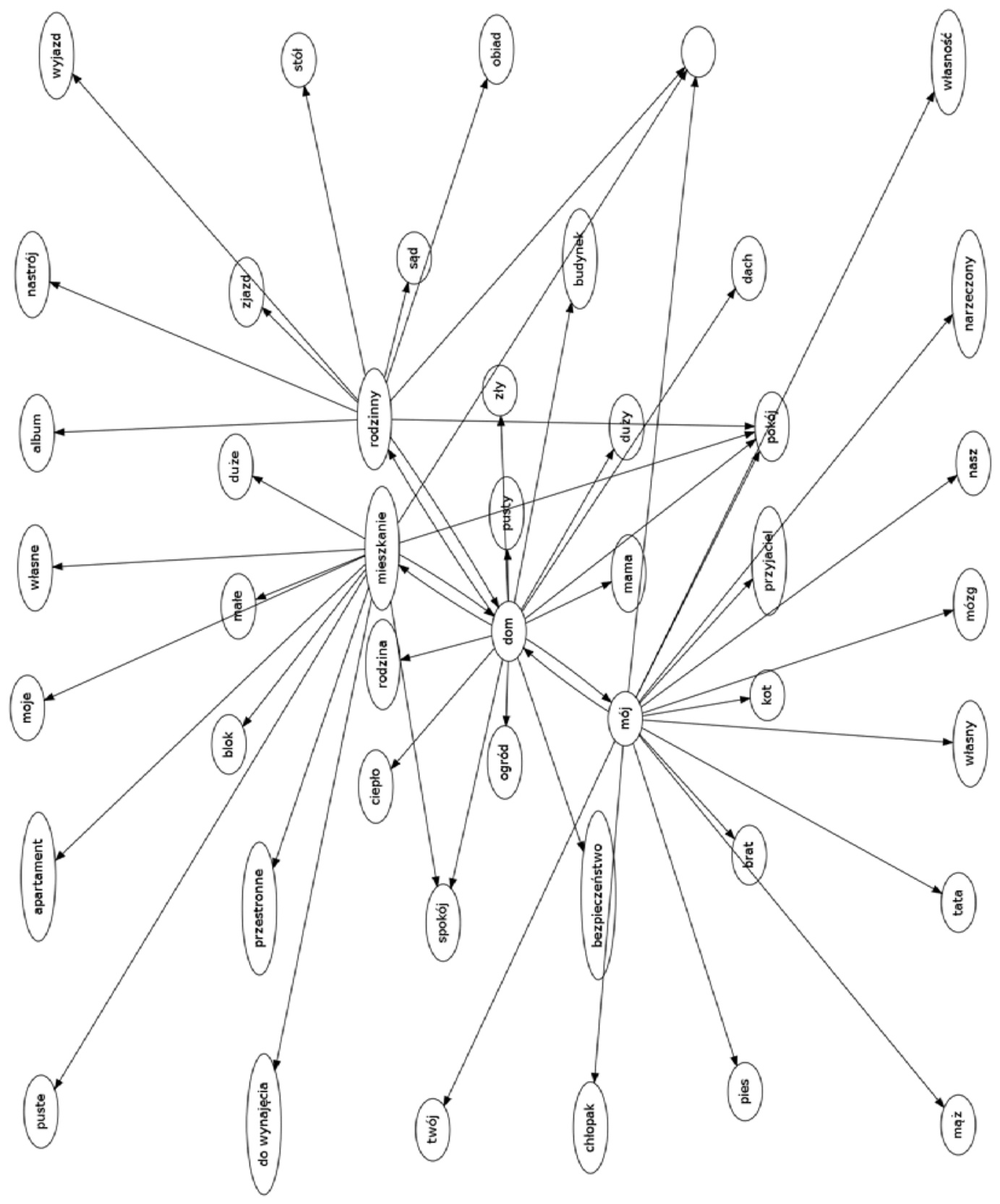


miotniki 18\%, czasowniki 9\%, a pozostałe 1\%. Pozostałe 592 węzły sieci zbudowanej za pomocą eksperymentu stanowią nazwy własne, które wchodzą w 950 powiązań.

Graficzną reprezentację węzła leksykalnego przedstawimy na przykładzie wyrazu dom, gdzie wyraźnie widać, że sieć zawiera powiązania dla dwu znaczeń 'budynek' oraz 'miejsce rodziny'. Chcąc zachować czytelność rysunku, pominęliśmy wszystkie powiązania, których siła była mniejsza niż 0,34 .

\subsection{Węzeł leksykalny a definicja słownikowa}

Ze względu na szczupłość miejsca przeanalizujemy tylko dwa przykłady węzłów leksykalnych rzeczownika. Porównamy znaczenie słownikowe z zawartością węzła leksykalnego, identyfikując jakość powiązań w węźle za pomocą wyznaczników, podając siłę powiązania wychodzącego (wyrażoną w procentach). Opis będzie także sygnalizować powiązania przychodzące, jeśli wystąpią. Wyrazy przytaczamy w takiej formie, w jakiej zostały napisane przez uczestników eksperymentu, oznaczając gwiazdką (*) formy błędne.

\subsubsection{Węzeł leksykalny księżyc}

Węzeł leksykalny wyrazu księżyc, który był bodźcem prymarnym, zawiera powiązania ze 170 wyrazami, których siłę powiązania obliczono na podstawie 870 odpowiedzi 30 badanych nie podało swojego skojarzenia do wyrazu księżyc. Porównywana z węzłem definicja znaczenia pochodzi ze „Słownika języka polskiego PWN” — dostęp on-line. Definicja ma postać: Księżyc — rzeczownik, r. m., 1. p., 1. «naturalny satelita Ziemi» 2. «ciało niebieskie krążące dookoła jakiejś planety»• księżycowy

Znaczenie pierwsze: 'naturalny satelita Ziemi' reprezentują powiązania klasyfikowane jako:

wiedza satelita 2,53 , ziemia 1,49 ; łącznie 4,02 oraz przychodzące ziemia 0,92 .

Znaczenie księżyc: 'ciało niebieskie krążące dookoła jakiejś planety’ ma powiązania klasyfikowane jako:

wiedza planeta 1,03 , planety 0,23 , ciało niebieskie 0,23 , galaktyka 0,23 , kosmos 0,5 ; łącznie 2,29 oraz przychodzące planeta 0,11 .

Łącznie oba znaczenia umieszczone w słowniku są identyfikowane w sieci przez powiązania wychodzące, których łączna siła wynosi 6,31 i powiązania przychodzące 1,03.

Najliczniejszy zbiór powiązań odnosi się do znaczenia wyrazu księżyc, które nie zostało bezpośrednio zdefiniowane w słowniku i można je zdefiniować jako obiekt będący naturalnym źródtem światła. Do tego znaczenia odnoszą się powiązania:

Paradygmatyczne:

komplementarność słońce 9,08, slonce*, 0,69, słońca 0,23 łącznie: 10 oraz przychodzące słońce 5,38. 
Syntagmatyc zne:

kształt petnia 7,24, w petni 6,55, okragły 0,57, kula 0,23 , nów 4,94, w nowiu 3,1, rogal 0,69 , półksiężyc 0,46 , sierp 0,23 , rogalik 0,46 , ser 0,46 oraz przychodzące petnia 34,11 , petny 8,35 , okragty 0,56 ;

kolor srebro 0,34, jasny 3,22, żótty 0,23;

właściwość swoista zaćmienie 0,23 ;

działanie świeci 5,63 , swieci* 0,23 oraz przychodzące świecić 0,34 ;

źródło światło 0,92 , blask 0,57 , jasność 0,34 oraz przychodzące światto 0,11 ;

komplet gwiazdy 3,91, gwiazda 0,46;

lokalizacja niebo 2,87;

lokalizacja w czasie noc 17,24 , pótnoc 0,23 , zmierzch 0,34 , ciemno 0,23 , zachód 0,23 oraz przychodzące noc 4,17 ;

wiedza podróż 0,34 , Armstrong 0,57, luna* 0,8, moon* 0,23;

stereotyp wilkołak 0,23 ;

ocena piękny 0,57 , piękno 0,23 ;

składnikowe Czarodziejka 0,23: „Czarodziejka z Księżyca” — japońska kreskówka.

Jak widzimy, encyklopedyczne definicje znaczenia wyrazu księżyc mają tylko niewielką liczbę powiązań wychodzących, których łączna siła powiązania wynosi 6,31 procent. Zdecydowanie liczniejsze są powiązania (łączna siła ponad 90 procent), odnoszące się do znaczenia: księżyc — naturalne źródło światła, którego nie podaje słownik. Powiązania paradygmatyczne stanowią niewielką część charakterystyki sieciowej tego znaczenia - tylko 10 procent. Ponieważ księżyc jest obiektem naturalnym percypowanym za pomocą wzroku, wśród powiązań syntagmatycznych dominują te, które można percypować za pomocą wzroku, a więc kolor, zmienny kształt i związana z tym właściwość swoista zaćmienie. Księżyc działa: świeci i wytwarza światło, ma swoją lokalizację w przestrzeni wyrażaną przez stosunek do innych obiektów (gwiazdy) oraz lokalizację w czasie (noc), która stawia go w opozycji do słońca świecącego w dzień. Powiązania reprezentujące wiedzę, stereotyp, ocenę i składnikowe są nieliczne. Podsumowując, można powiedzieć, że księżyc jako węzeł sieci naturalnych powiązań leksykalnych to: obiekt widoczny na niebie w nocy, świeci jasno (światłem koloru srebrnego), jest widoczny na tle gwiazd. Kształt księżyca zmienia się od nowiu (rogal, rogalik, półksiężyc, sierp) do pełni (okrągły, kula, ser). Jest przeciwieństwem słońca.

\subsubsection{Węzeł leksykalny owca}

Węzeł leksykalny wyrazu owca, który był bodźcem prymarnym, zawiera powiązania ze 166 wyrazami, których siłę powiązania obliczono na podstawie 877 odpowiedzi - 27 uczestników nie podało swojej odpowiedzi do wyrazu owca.

Porównywane z węzłem znaczenie pochodzi ze „Słownika Języka Polskiego PWN” — dostęp on-line. Definicja ma postać owca - rzeczownik, r. ż., 1. p., definicja SJP: «zwierzę roślinożerne o miękkiej, skręconej sierści, żyjące w stadzie». 
Słownikowe znaczenie wyrazu owca reprezentują następujące powiązania:

Paradygmatyc zne:

hiperonimia (okaz - typ): zwierzę 2,62 (hiperonim) oraz przychodzące zwierzę 3,72;

holonimia (część — całość): stado 0,8 ;

meronimia (całość — część): szerść ${ }^{*} 0,23$.

Syntagmatyc zne:

tekstura miękka 0,34, kudłata 0,23;

odżywianie trawa 0,23 .

Powiązania wychodzące łącznie: 4,45\% i powiązania przychodzące 3,72.

Pozostałe odpowiedzi rozszerzają definicję. W węźle leksykalnym wyrazu owca znajdujemy dodatkowe informacje, które etykietowane są przez następujące wyznaczniki:

Paradygmaty c zne:

komplementarność baran 11,0 oraz przychodzące baran 28,19;

ko-hiponimia koza 1,94, krowa 0,57 ;

meronimia (całość — część): skóra 0,23.

Syntagmatyczne:

rozmiar mała 0,11 ;

kolor biała 5,25;

tekstura puszysta 0,23 ;

działanie beczy 0,43 , beczenie 0,23 , bee 0,23 , pasie się 0,11 ;

użyteczność strzyżenie 0,23 , klonowanie 0,23 ;

miejsce charakterystyczne góry 1,03 , tąka 1,03 , hala 0,91 , pole 0,68 , pastwisko 0,46 , zagroda 0,23 , farma 0,23 ;

wspóldziałanie baca 0,68 , pasterz 0,57 , pies 0,34 ;

źródło mleko 0,11 , runo 0,46 oraz przychodzące baranina 5,31, mięso 0,81 ;

wiedza dolly ${ }^{9} 1,37$;

ocena miła 0,11 ;

składnikowe wilk 1,82 => wilk $w$ owczej skórze WSF: s. 619; czarna 23,49 oraz przychodzące czarna 7,63 => czarna owca WSF s.332; cała $1,03=>i$ wilk syty, $i$ owca cała WSF s. 619; pęd 0,23 => owczy pęd WSF s. 348; zbłąana 0,23 => zbłąkana owca WSF s. 332, błędna 0,11 => chodzić jak błędna owca WSF s. 332;

odległe wetna 10,83 oraz powiązania przychodzące: wetna 43,2, bawetna 0,11 , ser 0,34 , oscypek 0,23 .

${ }^{9}$ Owca Dolly - owca domowa, pierwsze sklonowane zwierzę (1996-2003) przez naukowców Iana Wilmuta i Keitha Campbella (Edynburg, Szkocja). 
Jak widzimy, powiązania wychodzące poza znaczenie zdefiniowane w słowniku stanowią zdecydowaną większość (ponad 90 procent) i powiązania te rozszerzają definicję słownikową wyrazu owca, wprowadzając kolejne elementy charakterystyki zwierzęcia, a więc: żyje w parze z baranem, dowiadujemy się o kolorze sierści owcy, poznajemy inne zwierzęta hodowane przez człowieka, dowiadujemy się, jak się zachowuje, jakie odgłosy wydaje, w jakich warunkach żyje, czym się żywi, w jakich miejscach przebywa, kto się nią opiekuje, jakie korzyści odnosi człowiek z hodowli owcy. Poza tym w węźle leksykalnym wyrazu owca występują powiązania wychodzące do wyrazów stanowiących fragment złożonych jednostek leksykalnych, które współtworzy wyraz owca (powiązania składnikowe).

Podsumowując, można powiedzieć, że nawet tak bardzo ograniczona analiza porównawcza pokazuje pewne właściwości opisu znaczenia w węźle leksykalnym empirycznej sieci powiązań leksykalnych. Widać bowiem wyraźnie, że sieciowy model znaczenia jest bogatszy od znaczenia definiowanego przez słownik.

\section{Podsumowanie}

Niniejszy tekst miał pokazać budowę i właściwości empirycznej sieci powiązań leksykalnych w taki sposób, by w podsumowaniu można było wskazać dalszy kierunek badań. Niewątpliwie dalsza analiza węzłów zbudowanych wokół bodźców prymarnych powinna pozwolić na stwierdzenie tego, czy sieć rozróżnia modele powiązań charakteryzujących np. osoby, zwierzęta, rośliny, rzeczy. Odrębna analiza powinna pokazać, jak jest reprezentowane znaczenie wieloznacznego wyrazu bodźca. Kolejnym pytaniem, na które może odpowiedzieć analiza węzła leksykalnego sieci, jest pytanie o to, czy sieć odwzorowuje ręcznie budowane taksonomie znaczeń obserwowane w słownikach, np. WordNet, czy ontologiach Cyc. Można wreszcie pokazać swoistość węzła leksykalnego definiowanego wyłącznie za pomocą powiązań przychodzących.

Empiryczna sieć powiązań leksykalnych dostarcza także materiału do innych analiz, które nie odwołują się do wszystkich właściwości sieci. Można bowiem badać właściwości tzw. powiązania zwrotnego, np. dla połączenia rzeczownik — przymiotnik, powiedzmy kapusta - kiszona i kiszona - kapusta. Można też badać, czy w sieci znajdują się sygnały tego, że grupa badanych miała kłopot ze zrozumieniem wyrazu bodźca, np. płonna - nadzieja 49,7 wobec płonna - miłość 1,95, kobieta 0,8 , wiara, taka, świe$c a$ wszystkie 0,7 . Można wreszcie badać, jak cechy gramatyczne bodźca wpływają na cechy gramatyczne odpowiedzi, np. biały — śnieg 20,48 wobec bialy - mleko 0,7, chmura 0,45 w zestawieniu z biała - flaga 9,57 wobec biata — śnieg 0,7, mleko 0,34.

$\mathrm{Na}$ koniec trzeba wspomnieć o coraz częstszych zastosowaniach empirycznej sieci leksykalnej w badaniach lingwistyczno-komputerowych. Najważniejsze wydają się prace poświęcone badaniu zależności tekst — sieć np. Rapp (2002), Wettler i inni (2005), Wandmacher i inni (2008), Schulte im Walde i inni (2012), także Gatkowska i inni (2013), Lubaszewski i inni (2015). Wydaje się, że analiza sieci, w której powią- 
zania sklasyfikowano za pomocą wyznaczników, mogłaby wnieść nowy punkt widzenia pozwalający lepiej zrozumieć zależność sieć — tekst.

\section{Bibliografia}

B ar t m i ń s ki J., 1988a, Definicja kognitywna jako narzędzie opisu konotacji, [w:] Konotacja, red. J. Bartmiński, Lublin, s. 169-183.

—1988b, Słownik ludowych stereotypów językowych. Założenia ogólne, [w:] Etnolingwistyka 1, red. J. Bartmiński, Lublin, s. 11-34.

Chom sk y N.,1965, Aspects of the Theory of Syntax, MIT Press, Cambridge Mass.

Clark H.H., 1970, Word Associations and Lingustic Theory, [w:] New Horizons in Linguistics, red. J. Lyons, s. 271-286.

De Deyne S., Storms G., 2008, Word associations: Network and semantic properties, Behavior Research Methods 40 (1), s. 213-231.

F illm or e Ch.J., 2000, FrameNet, The Work. The Product. The Applications, https://framenet.icsi.berkeley.edu.

Gatkowska I., Korzycki M., Lubaszewski W., 2013, Can Human Association Norm Evaluate Latent Semantic Analysis? [w:] Proceedings of the 10th NLPCS Workshop, Marseille, s. 92-104.

Gatk ow sk a I., 2014, Word Associations as a Linguistic Data, [w:] Languages in Contact 2012, t. 1, red. P. Chruszczewski, J. Rickford, K. Buczek, A. Knapik, J. Mianowski, Wrocław, s. 79-92.

Geeraerts D., 2010, Theories of Lexical Semantics, Oxford Linguistics.

Kent G.H., R os a n off A.J., 1910, A study of association in insanity, American Journal of Insanity 67 (37-96), s. 317-390.

Kis s G.R., Armstrong C., Milroy R., Piper J., 1973, An associative thesaurus of English and its computer analysis, [w:] The Computer and Literary Studies, red. A.J.Aitken, R.W. Bailey, Edinburgh, s. $153-165$.

K u r c z I., 1967, Polskie normy powszechności skojarzeń swobodnych na 100 słów z listy Kent-Rosanoffa, Studia Psychologiczne VIII, s. 122-255.

L u b a s ze w sk i i in., 2001, Słowniku fleksyjnym języka polskiego, dokument elektroniczny, Kraków

Lubaszewski W., Gatkowska I., Haręza M., 2015, Human Association Network and Text Collection, [w:] Natural Language Processing and Cognitive Science, red. B. Sharp, R. Delmonte, Berlin-New York, s. 101-114.

Lyons J., 1963, Structural Semantics. An Analysis of Part of the Vocabulary of Plato (Publ. of the Philological Society 20), Oxford.

- (red.), 1970, New Horizons in Linguistics, Harmondsworth.

— 1984 (1977), Semantyka, t. 1 (Semantics 1), thum. A. Weinsberg, Warszawa.

Me l'ču k I.A., 2007, Lexical Functions, [w:] Phraseology. An International Handbook of Contemporary Research, red. H. Burger, D. Dobrovol'skij, P. Kühn, N. Norrick, Berlin-New York, s. 119-131.

Mille r G.A., Beckwith R., Fellbaum Ch., Gross D., Miller K., 1998, Introduction to WordNet: An On-line Lexical Database, [w:] WordNet An Electronic Lexical Database, red. Ch. Fellbaum, Cambridge Mass.

Meling er A., We ber A., 2006, Database of Noun Associations for German, http://www.psycholing.es. uni-tuebingen.de/nag [dostęp: 03.05.2015].

Mos s H., Older L., 1996, Birkbeck word association norms, Psychology Press.

Murphy M.L., 2003 (2008), Semantic Relations and the Lexicon: Antonymy, Synonymy, and other Paradigms, Cambridge.

Nels on D.L., McEvoy C.L, Schreiber T.A., 1998, The University of South Florida word association, rhyme, and word fragment norms, www.usf.edu/FreeAssociation/ [data dostępu: 6.06.2013].

Pal er mo D.S., J en kin s J.J., 1964, Word Associations Norms: Grade School through College, Minneapolis. 
Postman L., Keppel G., 1970, Norms of Word Association, New York, Academic Press.

Poh1 A., 2009, Rozstrzyganie wieloznaczności, maszynowa reprezentacja znaczenia wyrazu i ekstrakcja znaczeń, [w:] Słowniki komputerowe i automatyczna ekstrakcja informacji z tekstu, red. W. Lubaszewski, Kraków.

R a p p R., 2002, The Computation of Word Associations: Comparing Syntagmatic and Paradigmatic Approaches, [w:] Proceedings of the $19^{\text {th }}$ International Conference on Computational Linguistics, Taipei.

Ruppenhofer J., Ellsworth M., Petruck M.R.L., Johnson C.R, Scheffczyk J., 2010, FrameNet II: Extended Theory and Practice, Berkeley.

S ch a n k R.C., 1975, Conceptual Information Processing, Amsterdam.

S chank R.C., A bels on R., 1977, Scripts Plans Goals and Understanding, Hillsdale NJ.

Schulte im Walde S., Borgwaldt S., Jauch R., 2012, Association Norms of German Noun Compounds, [w:] Proceedings of the 8th International Conference on Language Resources and Evaluation, Istanbul.

S o w a J.F., 2000, Knowledge Represetation. Logical, Philosophical, and Computational Foundations, Course Technology, Boston.

Steyvers M., Tenenbaum J.B., 2005, The Large-Scale Structure of Semantic Networks: Statistical Analyses and a Model of Semantic Growth, Cognitive Science 29, s. 41-78.

Uhr P., Klahold A., F athi M., 2013, Imitation of the Human Ability of Word Association, JSCSE 3 (3), s. 2251-7545.

Wandmacher T., Ovchinnik ova E., A lex androv T., 2008, Does Latent Semantic Analysis reflect human associations, [w:] Proceedings of the ESSLLI Workshop on Distributional Lexical Semantics.

Wettler M., Rapp R., S edlme ier P., 2005, Free word associations correspond to contiguities between words in text, Journal of Quantitative Linguistics 12 (2), s. 111-122.

Słownik języka polskiego, www.sjp.pwn.pl, on-line.

http://www.opencyc.org/

Wielki Słownik Frazeologiczny PWN z przysłowiami, oprac. A. Kłosińska, E. Sobol, A. Stankiewicz, Warszawa 2005.

\section{SUMMARY}

\section{Empirical Lexical Network}

Ke y w ord s: empirical network, lexical semantics, lexical relations, natural dictionary, computational linguistics.

Słow a kluc zow e: sieć empiryczna, semantyka leksykalna, relacje leksykalne, słownik naturalny, lingwistyka komputerowa.

The properties of experimentally built association networks were studied from many different points of view. The results of those investigations show that if one aims to treat an empirical network as a 'natural dictionary' suitable for text processing algorithms, one should develop a consistent and linguistically valid set of semantic relationships which may explain information borne by word associations. The aim of this paper is describe a preliminary set of relationships which are applicable to word associations, and show how those associations, if classified, define the meaning of a noun which is a node of the network. 